\title{
Effect of temperature on population growth and life table parameters of Nephus arcuatus (Coleoptera: Coccinellidae)
}

\author{
SARA ZARGHAMI ${ }^{1}$, Farhan KOCHEILI ${ }^{1}$, Mohammad S. MOSSADEGH ${ }^{1}$, Hossein ALLAHYARI ${ }^{2}$ \\ and ARASH RASEKH ${ }^{1}$
}

\begin{abstract}
${ }^{1}$ Shahid Chamran University of Ahvaz, Department of Plant Protection, Ahvaz, Khuzestan, Islamic Republic of Iran; e-mails: s-zarghami@phdstu.scu.ac.ir; kocheilif@yahoo.com; mossadegh_ms@yahoo.com; arashrasekh@gmail.com

${ }^{2}$ University of Tehran, Department of Plant Protection, Karaj 98511-2413270, Islamic Republic of Iran; e-mail: allahyar@ut.ac.ir
\end{abstract}

Key words. Coleoptera, Coccinellidae, Nephus arcuatus, Homoptera, Pseudococcidae, Nipaecoccus viridis, temperature, life table, biological control

\begin{abstract}
The development, reproduction and life table parameters of the predator Nephus arcuatus Kapur (Coleoptera: Coccinellidae), the most important predator of the spherical mealybug, Nipaecoccus viridis (Newstead) (Homoptera: Pseudococcidae) were studied at five constant temperatures $\left(15,20,25,30\right.$ and $35 \pm 1{ }^{\circ} \mathrm{C}, 65 \pm 5 \% \mathrm{RH}$ and a photoperiod of $14 \mathrm{~L}$ : 10D). The duration of total pre-adult stage was found to decrease with increase in temperature from 60.0 days at $20^{\circ} \mathrm{C}$ to 15.3 days at $35^{\circ} \mathrm{C}$. The oviposition period lasted 58.5, 44.7, 53.2 and 24.5 days at $20,25,30$ and $35^{\circ} \mathrm{C}$, respectively, with females laying an average of $164.8,415.2,660.4$ and 136.6 eggs, respectively, at these four temperatures. Life table data were analyzed using an age-stage, two-sex life table. The intrinsic rate of increase $\left(r_{m}=0.1540 \mathrm{~d}^{-1}\right)$, finite rate of increase $\left(\lambda=1.1666 \mathrm{~d}^{-1}\right)$ and net reproductive rate $\left(R_{0}=197.9\right.$ offspring $)$ were greatest at $30^{\circ} \mathrm{C}$. The shortest mean generation time $(T=30.6$ days $)$ was recorded at $35^{\circ} \mathrm{C}$. These results indicate that $N$. arcuatus can successfully survive and reproduce at temperatures of around $30^{\circ} \mathrm{C}$ and has the potential to be an effective biological control agent of $N$. viridis and other mealybugs in warm regions.
\end{abstract}

\section{INTRODUCTION}

This study concerns one of the most effective predators of mealybugs in warm regions, namely the recently described Nephus arcuatus Kapur (Coleoptera: Coccinellidae), which is indigenous to warm regions of Southwestern Iran (Löbl \& Smetana, 2007). It also occurs in Yemen and Saudi Arabia (Ramindo \& van Harten, 2000). This small coccinellid has a high searching capacity, especially in warm regions and is an important biological control agent of the spherical mealybug, Nipaecoccus viridis (Newstead) in orchards in Dezful, Southwestern Iran.

$N$. viridis is a polyphagous pest, which feeds on a wide range of ornamental plants and orchards crops throughout tropical and subtropical regions and a large part of the Pacific Basin (Sharaf \& Meyerdirk, 1987; Nechols, 1995) and occurs in South and Southwestern Iran (Moghadam, 2006). Symptoms of plants infested with $N$. viridis are curling and dwarfing of terminal growth, abortion of flowers, yellowing of leaves and abortion of fruit. Indirect damage results from production of sticky honeydew that facilitates the growth of black mould and reduces plant growth (AbdulRassoul, 1970; Sharaf \& Meyerdirk, 1987; Al-Rawy et al., 1997). Chemical control of mealybugs is often ineffective because they tend to live in protected locations and are also protected by the mealy wax covering their eggs and body (Joyce et al., 2001). In contrast, mealybugs are controlled by releases of either a single predator (Mani \& Thontadarya, 1989; Afifi et al., 2010) or parasitoid (Meyerdirk et al., 1988; Muniappan et al., 2006; Amarasekare et al., 2009), or of both (Kairo et al., 2000; Abd-Rabou, 2008).
Currently in Iran, Cryptolaemus montrouzieri Mulsant is used for the biological control of mealybugs in orchards and greenhouses. In some regions, however, probably due to unsuitable weather, lack of alternative prey (DeBach \& Hagen, 1964; Izhevsky \& Orlinsky, 1988; Yigit \& Canhilal, 1998) and the ants that attend mealybugs (Hernandez et al., 1999; Mossadegh et al., 2008b), this predator is not able to establish itself and is mass-reared and released each year in order to control mealybugs.

The use of a natural enemy to control a pest should be based on a comprehensive life table study of its natural enemies. In the case of coccinellids both males and females kill and eat prey and it is therefore important to include the effects of both sexes when evaluating their effectiveness as biological control agents. Female age-specific life table (Lewis, 1942; Leslie, 1945; Birch, 1948; Carey, 1993) deal only with female populations and ignores the variable developmental rates of individuals, stage differentiation and males in a population. In contrast, age-stage, two-sex life table developed by Chi \& Liu (1985) and Chi (1988) takes these factors into consideration. This type of life table has been used to describe the population characteristics of many insects and their natural enemies (Chi \& Yang, 2003; Gabre et al., 2005; Yu et al., 2005, 2013; Chi \& Su, 2006; Huang \& Chi, 2013).

Understanding the effect of the main abiotic factor, temperature, on the development and fecundity of $N$. arcuatus could be a useful way of predicting the activity and population dynamics of this predator in the field and of optimizing mass rearing under laboratory conditions. In the present 
study the effect of temperature on the population growth rate and life table parameters of $N$. arcuatus feeding on $N$. viridis was determined.

\section{MATERIAL AND METHODS}

\section{Insect culture}

The spherical mealybug, $N$. viridis was mass reared on potato sprouts (Solanum tuberosum) in boxes $(24 \times 16 \times 10 \mathrm{~cm})$ tightly covered by a fine mesh net. Adults of $N$. arcuatus were originally collected from an orchard infested with $N$. viridis in Dezful $\left(48^{\circ} 30^{\prime} \mathrm{E}, 32^{\circ} 20^{\prime} \mathrm{N}\right)$, Khuzestan province, Southwestern Iran in April 2010. N. arcuatus adults were placed in rearing boxes containing sprouted potatoes infested with $N$. viridis. These boxes were checked daily and fresh infested sprouts were added as needed. The stock colonies of $N$. arcuatus and $N$. viridis was maintained in an incubator at $25 \pm 1{ }^{\circ} \mathrm{C}, 65 \pm 5 \% \mathrm{RH}$ and $14 \mathrm{~L}: 10 \mathrm{D}$ photoperiod for three generations before they were used in the experiments. To maintain genetic variability, adults of $N$. arcuatus were field collected and mixed with the stock every few months.

\section{Biology and life table parameters}

This study was conducted at 5 constant temperatures: 15,20 , 25,30 and $35 \pm 1{ }^{\circ} \mathrm{C}, 65 \pm 5 \% \mathrm{RH}$ and a photoperiod of $14 \mathrm{~L}: 10 \mathrm{D}$. Before initiating the experiment, a colony of the coccinellid was maintained at either $15,20,25,30$ or $35^{\circ} \mathrm{C}, 65 \pm 5 \% \mathrm{RH}$ and a photoperiod of $14 \mathrm{~L}: 10 \mathrm{D}$ for one generation. To have a cohort of eggs of the same age $(<8 \mathrm{~h}), 50$ paired $N$. arcuatus were obtained from the stock population kept at each temperature and were released into a colony of mealybugs in a cylindrical container $(18 \times 8 \mathrm{~cm})$ covered with fine mesh net for ventilation. Eight hours later, 100 eggs were removed and placed in Petri dishes $(6 \times 1 \mathrm{~cm})$, individually in order to avoid cannibalism, and were maintained under the same conditions in which they were laid. Newly emerged larvae were transferred to individual plastic containers $(3 \times 3 \mathrm{~cm})$, containing $1.5 \%$ agar where they were reared on a piece of sprouted potato infested with $N$. viridis that had been placed upside down in the middle of the container. Observations were made daily. Larval development and mortality were assessed every $12 \mathrm{~h}$. After the emergence of adults, males and females were paired and checked daily to record survival and fecundity.

\section{Statistical analysis}

The developmental time of individuals, both male and female, and those dying before reaching the adult stage and the fecundity of $N$. arcuatus at different temperatures were analyzed using an age-stage, two-sex life table (Chi \& Liu, 1985) and following the procedure described by Chi (1988). The adult pre-oviposition period (APOP) (the duration from adult emergence to first oviposition) and total pre-oviposition period (TPOP) (the duration from egg to first oviposition) were calculated. The population parameters (net reproductive rate $\left(R_{0}\right)$, intrinsic rate of increase $(r)$, finite rate of increase $(\lambda)$ and mean generation time $(T)$ were also calculated. The age-stage life expectancy $\left(e_{x j}\right)$ was calculated according to $\mathrm{Chi} \& \mathrm{Su}$ (2006). The intrinsic rate of increase $\left(r_{m}\right)$ was estimated using the iterative bisection method and Euler-Lotka equation with age indexed from 0 (Goodman, 1982):

$$
\sum_{x=0}^{\infty} e^{-r(x+1)} \operatorname{lxm} x=1
$$

The finite rate of increase $(\lambda)$, net reproductive rate $\left(R_{0}\right)$ and mean generation time $(T)$ were calculated as follows:

$$
\begin{aligned}
& \lambda=e^{r} \\
& R_{0}=\sum_{x=0}^{\infty} l x m x \\
& T=\frac{\ln R_{0}}{r_{m}}
\end{aligned}
$$

The relationship between the net reproductive rate $\left(R_{0}\right)$ and mean female fecundity $(F)$ based on the two-sex life table is that provided by Chi's (1988) equation:

$$
R_{0}=\frac{N_{f}}{N}
$$

Where $N$ is the total number of eggs (100) used in the life table study and $N_{f}$ the number of female adults developed from $N$ eggs. Data analysis and population parameters (Chi, 1988; Chi \& Liu, 1985) were calculated using the TWOSEX-MSChart computer program (Chi, 2012). To estimate the means, variances and standard errors of the population parameters, bootstrap techniques were used (Erfon \& Tibshirani, 1993). To generate less variable results, 10,000 iterations were performed (Yu et al., 2013). We used the Tukey-Kramer test (Dunnett, 1980) to compare the differences among treatments.

\section{RESULTS}

$N$. arcuatus did not lay eggs at $15^{\circ} \mathrm{C}$, so only its bio-

\begin{tabular}{|c|c|c|c|c|c|c|c|c|}
\hline \multirow{3}{*}{ Statistic parameters } & \multicolumn{8}{|c|}{ Temperature } \\
\hline & \multicolumn{2}{|l|}{$20^{\circ} \mathrm{C}$} & \multicolumn{2}{|l|}{$25^{\circ} \mathrm{C}$} & \multicolumn{2}{|l|}{$30^{\circ} \mathrm{C}$} & \multicolumn{2}{|l|}{$35^{\circ} \mathrm{C}$} \\
\hline & mean $\pm \mathrm{SE}$ & $n$ & mean $\pm \mathrm{SE}$ & $n$ & mean $\pm \mathrm{SE}$ & $n$ & mean $\pm \mathrm{SE}$ & $n$ \\
\hline \multicolumn{9}{|l|}{ Developmental time (days)* } \\
\hline Egg & $12.1 \pm 0.1 \mathrm{a}$ & 84 & $6.4 \pm 0.1 \mathrm{~b}$ & 94 & $3.9 \pm 0.0 \mathrm{c}$ & 91 & $3.6 \pm 0.0 \mathrm{c}$ & 68 \\
\hline 1st instar & $7.1 \pm 0.1 \mathrm{a}$ & 78 & $3.9 \pm 0.0 \mathrm{~b}$ & 80 & $2.2 \pm 0.0 \mathrm{c}$ & 86 & $1.8 \pm 0.0 \mathrm{~d}$ & 59 \\
\hline 2nd instar & $5.6 \pm 0.1 \mathrm{a}$ & 71 & $2.5 \pm 0.0 \mathrm{~b}$ & 78 & $1.3 \pm 0.0 \mathrm{c}$ & 86 & $1.2 \pm 0.0 \mathrm{c}$ & 58 \\
\hline 3rd instar & $6.2 \pm 0.1 \mathrm{a}$ & 67 & $2.8 \pm 0.0 \mathrm{~b}$ & 77 & $1.5 \pm 0.0 \mathrm{c}$ & 85 & $1.5 \pm 0.0 \mathrm{c}$ & 57 \\
\hline 4th instar & $11.9 \pm 0.2 \mathrm{a}$ & 52 & $4.7 \pm 0.1 \mathrm{~b}$ & 74 & $2.6 \pm 0.0 \mathrm{c}$ & 82 & $2.7 \pm 0.1 \mathrm{c}$ & 54 \\
\hline Pre-pupa & $4.2 \pm 0.1 \mathrm{a}$ & 48 & $2.2 \pm 0.1 \mathrm{~b}$ & 71 & $1.0 \pm 0.0 \mathrm{c}$ & 82 & $1.1 \pm 0.0 \mathrm{c}$ & 49 \\
\hline Pupa & $13.2 \pm 0.2 \mathrm{a}$ & 44 & $7.1 \pm 0.1 \mathrm{~b}$ & 68 & $5.1 \pm 0.1 \mathrm{c}$ & 78 & $3.6 \pm 0.1 \mathrm{~d}$ & 46 \\
\hline Total pre-adult & $60.0 \pm 0.5 \mathrm{a}$ & 44 & $29.5 \pm 0.2 b$ & 78 & $17.6 \pm 0.1 \mathrm{c}$ & 78 & $15.3 \pm 0.1 \mathrm{c}$ & 46 \\
\hline Total pre-adult mortality (\%) & $56 \%$ & 56 & $32 \%$ & 32 & $23 \%$ & 23 & $54 \%$ & 54 \\
\hline
\end{tabular}
logical characteristics at $20,25,30$ and $35^{\circ} \mathrm{C}$ are recorded (Table 1). Out of the cohort of 100 eggs at the beginning of each experiment, 84, 94, 91 and 68 eggs hatched at 20 ,

TABLE 1. Mean ( \pm SEM) developmental time and pre-adult mortality of $N$. arcuatus fed on $N$. viridis at four constant temperatures.

* Values in rows followed by the same letter are not significantly different based on a Tukey-Kramer test with $\alpha=0.05$. 
TABLE 2. Mean ( \pm SEM) preoviposition period (APOP), total preoviposition period (TPOP), oviposition period, adult longevity and fecundity of $N$. arcuatus fed on $N$. viridis at four constant temperatures.

\begin{tabular}{|c|c|c|c|c|c|c|c|c|}
\hline \multirow{3}{*}{ Statistics } & \multicolumn{8}{|c|}{ Temperature } \\
\hline & \multicolumn{2}{|l|}{$20^{\circ} \mathrm{C}$} & \multicolumn{2}{|l|}{$25^{\circ} \mathrm{C}$} & \multicolumn{2}{|l|}{$30^{\circ} \mathrm{C}$} & \multicolumn{2}{|l|}{$35^{\circ} \mathrm{C}$} \\
\hline & mean $\pm \mathrm{SE}$ & $n$ & mean $\pm \mathrm{SE}$ & $n$ & mean $\pm \mathrm{SE}$ & $n$ & mean $\pm \mathrm{SE}$ & $n$ \\
\hline \multicolumn{9}{|l|}{ Adult longevity (days) } \\
\hline Female & $157.3 \pm 12.6 \mathrm{a}^{*} \mathrm{~A} * *$ & 25 & $93.8 \pm 10.7 \mathrm{bA}$ & 23 & $116.5 \pm 6.6 \mathrm{bA}$ & 30 & $44.6 \pm 4.2 \mathrm{cA}$ & 24 \\
\hline Male & $144.4 \pm 13.0 \mathrm{aA}$ & 19 & $121.8 \pm 10.1 \mathrm{bA}$ & 45 & $86.1 \pm 6.3 \mathrm{cB}$ & 48 & $42.4 \pm 2.6 \mathrm{dA}$ & 22 \\
\hline \multicolumn{9}{|l|}{ Adult preoviposition (days) } \\
\hline APOP & $11.6 \pm 0.8 \mathrm{a}$ & 20 & $5.8 \pm 0.3 \mathrm{~b}$ & 22 & $4.2 \pm 0.1 \mathrm{c}$ & 30 & $3.4 \pm 0.4 \mathrm{c}$ & 20 \\
\hline ТРОР & $70.1 \pm 1.2 \mathrm{a}$ & 20 & $35.5 \pm 0.3 \mathrm{~b}$ & 22 & $21.9 \pm 0.2 \mathrm{c}$ & 30 & $18.7 \pm 0.4 \mathrm{~d}$ & 20 \\
\hline Oviposition days (days) & $58.5 \pm 1.2 \mathrm{a}$ & 20 & $44.7 \pm 1.4 \mathrm{~b}$ & 22 & $53.2 \pm 0.6 \mathrm{~b}$ & 30 & $24.5 \pm 0.7 \mathrm{c}$ & 20 \\
\hline Fecundity (egg/female) & $164.8 \pm 25.0 \mathrm{c}$ & 25 & $415.2 \pm 57.8 \mathrm{~b}$ & 23 & $660.4 \pm 37.9 \mathrm{a}$ & 30 & $136.6 \pm 24.0 \mathrm{c}$ & 24 \\
\hline Maximum daily fecundity & 15 & & 29 & & 32 & & 22 & \\
\hline
\end{tabular}

Values in rows with the same small* letters are not significantly different based on a Tukey-Kramer test with $\alpha=0.05$.Values in columns (for longevity) with the same capital** letters are not significantly different based on a Tukey-Kramer test with $\alpha=0.05$.

25,30 and $35^{\circ} \mathrm{C}$, respectively. The total developmental time from egg hatch to adult emergence decreased significantly with increase in temperature, with the longest period recorded at $20^{\circ} \mathrm{C}$ and shortest at $35^{\circ} \mathrm{C}$. The lowest total pre-adult mortality occurred at $30^{\circ} \mathrm{C}$ followed by that at 25,20 and $35^{\circ} \mathrm{C}$, respectively. The adult pre-oviposition period (APOP), total pre-oviposition period (TPOP) and oviposition period decreased significantly with increase in temperature. Fecundity was highest at $30^{\circ} \mathrm{C}$ and lowest at $35^{\circ} \mathrm{C}$ (Table 2). Adult longevity at $20^{\circ} \mathrm{C}$ was significantly longer than that of adults reared at other temperatures. For all temperatures except $25^{\circ} \mathrm{C}$, females lived longer than males but not significantly so.

The age-stage specific survival rate $\left(s_{x j}\right)$ curve of $N$. arcuatus indicates the probability of a newborn larva surviving to age $x$ and stage $j$ (Fig. 1). Due to the variation in the developmental rates between individuals there are overlaps in the stage survival rate. The probability that a newly laid egg will develop to the adult stage increases with increase in temperature between 20 and $30^{\circ} \mathrm{C}$ and then decreases at $35^{\circ} \mathrm{C}$. Both females and males developing at $20^{\circ} \mathrm{C}$ survived longer than those developing at other temperatures (Fig. 1). Because greater numbers of females survived than males, the proportion of females was greater at all temperatures except $25^{\circ} \mathrm{C}$.

The age-specific survival rate $\left(l_{r}\right)$ decreased with increasing temperature. In contrast, the percentage of time females spent ovipositing increased with increase in temperature. The highest peaks for age-stage specific fecun- dity $\left[f_{x 8}\right.$ (i.e. the female is the eight life stage) $]$, age-specific fecundity $\left(m_{x}\right)$ and age specific maternity $\left(l_{x} m_{x}\right)$ were recorded at $30^{\circ} \mathrm{C}$ (Fig. 2).

The negative effect of a decrease in temperature on reproduction in $N$. arcuatus can be observed in the age-specific reproductive curve $\left(v_{x j}\right)$. The maximum reproductive peak of females reared at $20^{\circ} \mathrm{C}$ occurred much later than that of females reared at $30^{\circ} \mathrm{C}$ (Fig. 3).

The age-stage specific life expectancy $\left(e_{x j}\right)$ of a newborn $\left(e_{01}\right)$ is exactly the same as the mean longevity. The maximum life expectancy of all stages of $N$. arcuatus was recorded at $20^{\circ} \mathrm{C}$ (Fig. 4). Life expectancy decreased gradually with age since the study was conducted in the laboratory and thus unaffected by adverse effects of field conditions.

The mean and standard errors of the population parameters are presented in Table 3. Temperature had a significant effect on intrinsic rate of increase $\left(r_{m}\right)$. Increasing values of $0.0377,0.0878$ and $0.1540 \mathrm{~d}^{-1}$ were recorded at 20,25 and $30^{\circ} \mathrm{C}$, respectively. At $35^{\circ} \mathrm{C}$, however, there was a reduction in the value to $0.1132 \mathrm{~d}^{-1}$. The rate of population growth was greatest at $30^{\circ} \mathrm{C}$ and lowest at $20^{\circ} \mathrm{C}$. The finite rate of increase was greatest at $30^{\circ} \mathrm{C}$. The longest mean generation time was recorded at $20^{\circ} \mathrm{C}$ and the shortest at $35^{\circ} \mathrm{C}$. The highest net reproductive rate $\left(R_{0}\right)$ was recorded at $30^{\circ} \mathrm{C}$.

All of our results for $N$. arcuatus reared at different temperatures are consistent with the relationships of equation 5. If a life table is constructed based on adult age and ig-

TABLE 3. Mean ( \pm SEM) population parameters of $N$. arcuatus fed on $N$. viridis at four constant temperatures.

\begin{tabular}{lcccc}
\hline \multirow{2}{*}{ Parameters } & \multicolumn{4}{c}{ Temperature } \\
\cline { 2 - 5 } & $20^{\circ} \mathrm{C}$ & $25^{\circ} \mathrm{C}$ & $30^{\circ} \mathrm{C}$ & $35^{\circ} \mathrm{C}$ \\
\hline$r$ (days $\left.^{-1}\right)$ & $0.0377 \pm 0.0026 \mathrm{~d}$ & $0.0878 \pm 0.0047 \mathrm{c}$ & $0.1540 \pm 0.0056 \mathrm{a}$ & $0.1132 \pm 0.0094 \mathrm{~b}$ \\
$\lambda$ (days $\left.^{-1}\right)$ & $1.0386 \pm 0.0027 \mathrm{~d}$ & $1.0918 \pm 0.005 \mathrm{c}$ & $1.1666 \pm 0.0067 \mathrm{a}$ & $1.1199 \pm 0.0105 \mathrm{~b}$ \\
$R_{0}$ (offspring) & $41.2 \pm 9.1 \mathrm{c}$ & $95.4 \pm 21.6 \mathrm{~b}$ & $197.9 \pm 32.2 \mathrm{a}$ & $32.6 \pm 8.0 \mathrm{c}$ \\
$T$ (days) & $97.6 \pm 1.7 \mathrm{a}$ & $51.5 \pm 1.1 \mathrm{~b}$ & $34.1 \pm 0.4 \mathrm{c}$ & $30.6 \pm 0.7 \mathrm{c}$ \\
\hline
\end{tabular}

Values in rows with the same small letter are not significantly different based on a Tukey-Kramer test with $\alpha=0.05$. 

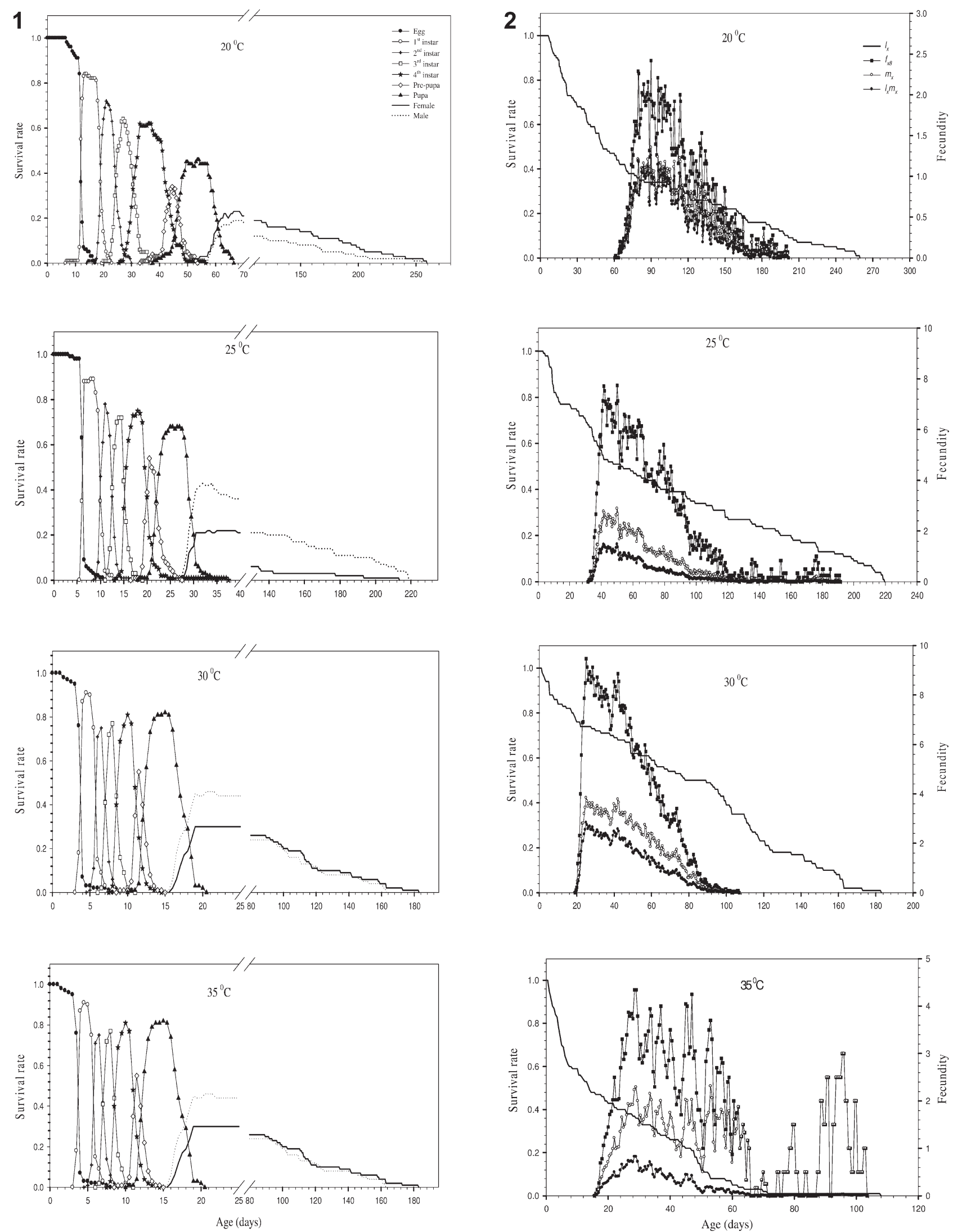

Figs 1-2. 1 - age-stage specific survival rate $\left(s_{x j}\right)$ calculated for $N$. arcuatus fed on $N$. viridis at four constant temperatures; 2 - age-specific survival rate $\left(l_{x}\right)$, age-stage specific fecundity $\left(f_{x 8}\right)$, age-specific fecundity $\left(m_{x}\right)$ and age-specific maternity $\left(l_{x} m_{x}\right)$ calculated for $N$. arcuatus fed on $N$. viridis at four constant temperatures. 

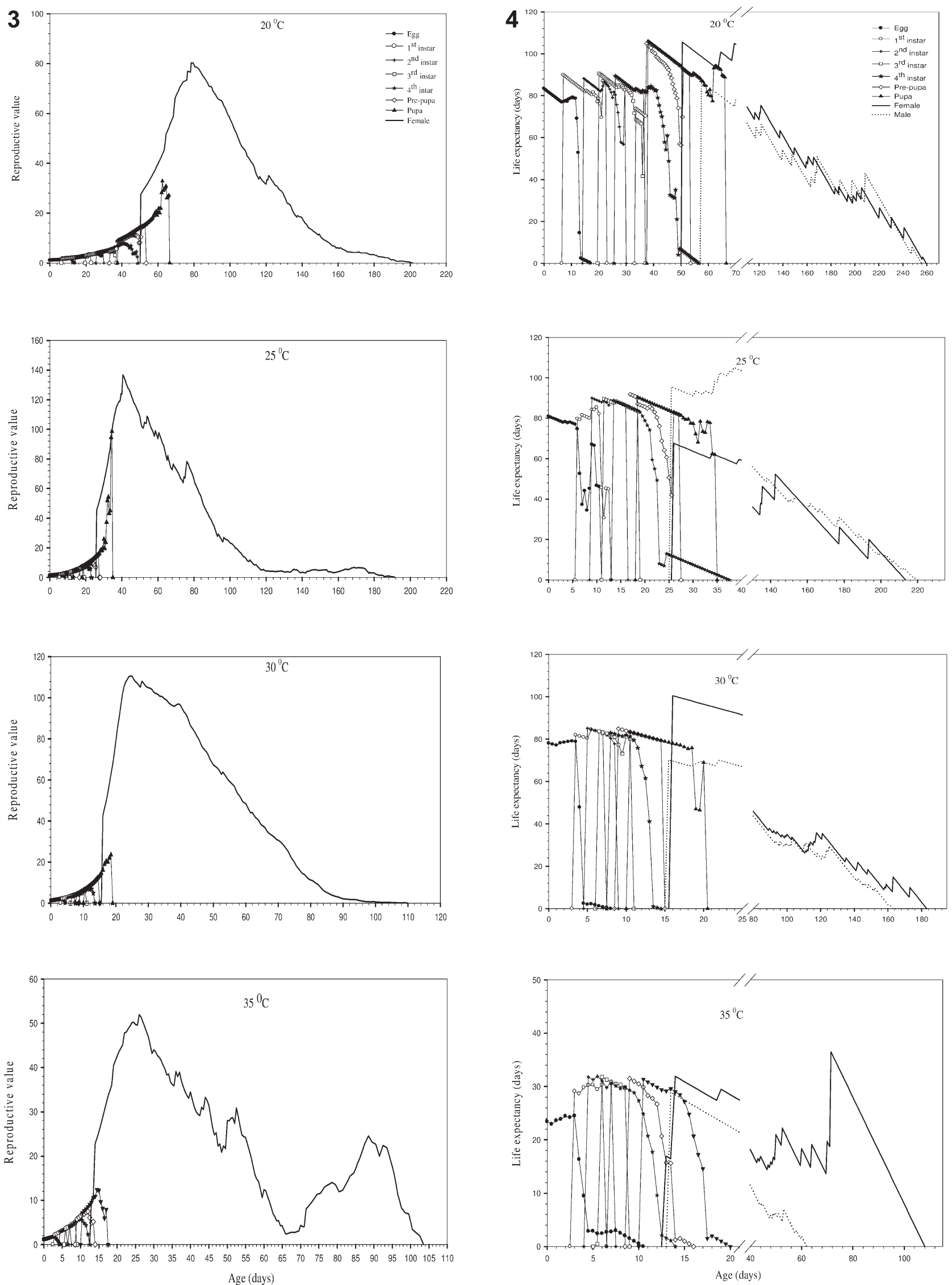

Figs 3-4. 3-age-specific reproductive value $\left(v_{x j}\right)$ calculated for $N$. arcuatus fed on $N$. viridis at four constant temperatures; 4 -agestage life expectancy $\left(e_{x j}\right)$ calculated for $N$. arcuatus fed on $N$. viridis at four constant temperatures. 
nores pre-adult mortality, it will provide an erroneous relationship between mean fecundity and net reproductive rate (Chi \& Yang, 2003; Yu et al., 2005; Chi \& Su, 2006).

\section{DISCUSSION}

One of the main factors influencing the biology, ecology and dynamics of pests and their natural enemies, is temperature (Jervis \& Copland, 1996). In the southwest of Iran the climate is hot and dry, which is suitable for mealybugs (Moghadam, 2006; Mossadegh et al., 2008a, 2012; Alizadeh et al., 2013). C. montrouzieri, a predator of mealybugs, was introduced into this region and is often released into orchards to control $N$. viridis. This predator is native to Australia and adapted to tropical climates (Gautam \& Parasram, 1996). The optimum temperature for its development is reported to be $30^{\circ} \mathrm{C}$ (Babu \& Azam, 1987) and temperatures above $42^{\circ} \mathrm{C}$ are lethal after even a short period (Solangi et al., 2013). In Southwestern Iran only one spring generation is possible and, as the temperature during summer is very high, its reproduction and other activities are suppressed (Mossadegh et al., 2008a). Although the average temperatures in this region ranged from $36.7^{\circ} \mathrm{C}$ in July to $35.6{ }^{\circ} \mathrm{C}$ in August over the period 2008 to 2012, high densities of $N$. arcuatus were observed in orchards and on ornamental plants infested with mealybugs (authors field observation). $N$. arcuatus is considered to be the most effective predator of Maconellicoccus hirsutus Green, because it is abundant and active for long periods of the year, especially during the hot summer months. For these reasons Allizadeh et al. (2013) introduced it into Ahvaz in Southwestern Iran. In the study reported here we found that an increase in temperature led to a reduction in the developmental period of pre-adult stages of $N$. arcuatus. Our results are similar to those of Canhilal et al. (2001) and Kontodimas et al. (2007) for other species of Nephus. The survival of pre-adult stages was greatest and pre-adult mortality least at $30^{\circ} \mathrm{C}$. At $30^{\circ} \mathrm{C}$ the mortality rate of the immature stages of Nephus includens Kirsch is lowest (34.4\% mortality) and highest at $35^{\circ} \mathrm{C}(71.6 \%$ mortality) (Canhilal et al., 2001). In our study pre-adult mortality at $35^{\circ} \mathrm{C}$ was lower, indicating that $N$. arcuatus is less sensitive than $N$. includens to temperatures above $30^{\circ} \mathrm{C}$. The females were most fecund at $30^{\circ} \mathrm{C}$ and more fecund than values reported for other pseudococcid predators such as $N$. includens (162.8 eggs), Nephus bisignatus Boheman (96.88 eggs) (Kontodimas et al., 2007), Nephus kreissli Fürsch \& Uygun (122.6 eggs) (Mustu \& Klincer, 2013), Nephus reunioni Fürsch (177.1 eggs) (Izhevsky \& Orlinsky, 1988) and C. montrouzieri, the key competitor in controlling mealybugs (510 eggs) (Fand et al., 2010) and (486.9 eggs) (Solangi et al., 2012).

Fisher (1958) defines the reproductive value as the contribution of an individual to the future population. The earlier occurrence of the reproductive peak at $30^{\circ} \mathrm{C}$ shows that increasing the temperature from 20 to $35^{\circ} \mathrm{C}$ resulted in an increase in the rate of increase of the population. Because the life expectancy value is calculated using the age-stage survival rate $\left(s_{x j}\right)$, which does not assume the population reaches a stable age-stage distribution, it can be used to predict the survival of a population (Chi \& Su, 2006). By using life expectancy we can predict that both males and females of $N$. arcuatus can be expected to live for more than 5 months or 1 month at 20 and $35^{\circ} \mathrm{C}$, respectively. However, this value could be different under field conditions where both biotic and abiotic factors vary. Solangi et al. (2013) report that $C$. montrouzieri can survive 33.13 days at $35^{\circ} \mathrm{C}$, which is substantially shorter than $N$. arcuatus can survive at the same temperature.

The life table is a useful tool for evaluating the effectiveness of natural enemies for controlling pests under various climatic conditions and in different habitats (Birch, 1948; Jervis \& Copland, 1996). Among life table parameters $\left(R_{0}\right.$, $\left.r_{m}, \lambda, T\right)$, the $r_{m}$ parameter is especially interesting because it integrates mortality and fertility into a single value. The maximum intrinsic rate of increase for $N$. arcuatus feeding on $N$. viridis was recorded at $30^{\circ} \mathrm{C}$ and is greater than the value for $N$. kreissli feeding on Planococcus citri Risso at $28^{\circ} \mathrm{C}\left(r_{m}=0.0709\right)$ (Mustu \& Klincer, 2013), $N$. includens feeding on $P$. citri at $30^{\circ} \mathrm{C}\left(r_{m}=0.086\right), N$. bisignatus feeding on $P$. citri at $25^{\circ} \mathrm{C}\left(r_{m}=0.060\right)$ (Kontodimas et al., 2007) and C. montrouzieri feeding on P. citri $\left(r_{m}=0.092\right)$ (Ghorbanian et al., 2011) or M. hirsutus $\left(r_{m}=0.135\right)$ at $27^{\circ} \mathrm{C}$ (Persad \& Khan, 2002).

Based on our results the optimal temperature for population growth of $N$. arcuatus is $30^{\circ} \mathrm{C}$. Because it has a greater survival and longevity, higher reproductive capacity and voracious appetite, and can feed on a wide range of prey than other pseudococcid predators, we conclude that it should be possible to introduce and use $N$. arcuatus as an effective biological control agent of mealybugs in regions with the same climatic conditions as the southwestern part of Iran.

ACKNOWLEDGEMENTS. The authors wish to express their sincere gratitude to H. Fürsch for identification of Nephus arcuatus Kapur and F.R. Hunter Fujita for revising and very useful suggestions for improving the manuscript.

\section{REFERENCES}

AbD-Rabou S. 2008: Biological control of Saccharicoccus sacchari (Coccoidea: Pseudococcidae) on sugar cane in Egypt using imported and indigenous natural enemies. In Branco M., Franco J.C. \& Hodgson C.J. (eds): Proceedings of the XI International Symposium on Scale Insect Studies, Oeiras, Portugal, 24-27 September 2007. ISA Press, Lisbon, pp. 277-284.

AbDul-Rassoul M.S. 1970: Notes on Nipaecoccus vastator (Maskell) (Coccidae, Homoptera). A serious pest of citrus trees and various plants - first record from Iraq. — Bull. Iraq Nat. Hist. Mus. 4(4): 105-108.

Afifi A.I., El Arnaouty S.A., Attia A.R. \& El Metwally Abd Alla A. 2010: Biological control of citrus mealybug, Planococcus citri (Risso) using coccinellid predator Cryptolaemus montrouzieri Muls. — Pakistan J. Biol. Sci. 13: 216-222.

Alizadeh M.S., Mossadegh M.S. \& Esfandiari M. 2013: Natural enemies of Maconelilcoccus hirstus (Green) (Hemiptera: Pseudococcidae) and their population fluctuations in Ahvaz, South West of Iran. - J. Crop Prot. 2(1): 13-21.

Al-Rawy M.A., Kaddou I.K. \& Al-Omar M.A. 1997: The present status of the spherical mealybug, Nipaecoccus vastator 
(Maskell) (Homoptera: Pseudococcidae) in Iraq. - Bull. Biol. Res. Cent (Baghdad) 8: 3-15.

Amarasekare K.G., Mannion C.M. \& Epsky N.D. 2009: Efficiency and establishment of three introduced parasitoids of the mealybug Paracoccus marginatus (Hemiptera: Pseudococcidae). - Biol. Contr. 51: 91-95.

BaBU T.R. \& AzAm K.M. 1987: Biology of Cryptolaemus montrouzieri Mulsant, (Coccinellidae: Coleoptera) in relation with temperature. - Entomophaga 32: 381-386.

BIRCHL L.C. 1948: The intrinsic rate of natural increase of an insect population. - J. Anim. Ecol. 17: 15-26.

Canhilal R., Uygun N. \& CARNER G.R. 2001: Effects of temperature on development and reproduction of a predatory beetle, Nephus includens Kirsch (Coleoptera: Coccinellidae). $-J$ Agr. Urban Entomol. 18: 117-125.

CARey J.R. 1993: Applied Demography for Biologists with Special Emphasis on Insects. Oxford University Press, New York, 224 pp.

CHI H. 1988: Life-table analysis incorporation both sexes and variable development rate among individual. - Environ. Entomol. 17: 26-34.

CHI H. 2012: TWOSEX-MSChart: A Computer Program for the Population Projection Based on the Stage, Two-sex Life Table. Available from: http:<//140.120.197.173/Ecology $>$.

CHI H. \& Liv H. 1985: Two new methods for the study of insect population ecology. - Bull. Inst. Zool. Acad. Sin. 24: 224-240.

CHI H. \& Su H.Y. 2006: Age-stage, two-sex life tables of Aphidius gifuensis (Ashmead) (Hymenoptera: Braconidae) and its host Myzus persicae (Sulzer) (Homoptera: Aphididae) with mathematical proof of the relationship between female fecundity and the net reproductive rate. - Environ. Entomol. 35: 10-21.

ChI H. \& YANG T.C. 2003: Two-sex life table and predation rate of Propylaea japonica Thunberg (Coleoptera: Coccinellidae) fed on Myzus persicae (Sulzer) (Homoptera: Aphididae). - Environ. Entomol. 32: 327-333.

Debach P. \& Hagen K.S. 1964: Manipulation of Entomophagous species. In Debach P. \& Schlinger E.I. (eds): Biological Control of Insect Pests and Weeds. Chapman \& Hall, London, pp. 429-458.

DunETT C.W. 1980: Pairwise multiple comparisons in the homogeneous variance, unequal sample size case. - J. Am. Statist. Assoc. 75: 789-795.

ERfon B. \& TibshiRAni R.J. 1993: An Introduction to the Bootstrap. Chapman and Hall, New York, 444 pp.

Fand B.B., Gautam R.D. \& Suroshe S.S. 2010: Comparative biology of four coccinellid predators of solenopsis mealybug, Phenacoccus solenopsis Tinsley (Hemiptera: Pseudococcidae). - J. Biol. Contr. 24: 35-41.

Fisher R.A. 1958: The Genetical Theory of Natural Selection. 2nd rev. ed. Dover, New York, 287 pp.

Gabre R.M., Adham F.K. \& Chi H. 2005: Life table of Chrysomya megacephala (Fabricius) (Diptera: Calliphoridae). Acta Oecol. 27: 179-183.

Ghorbanian S., Aghdam H.R., Ghajarieh H. \& Malkeshi S.H. 2011: Life cycle and population growth parameters of Cryptolaemus montrouzieri Mulsant (Col.: Coccinellidae) reared on Planococcus citri (Risso) (Hem.: Pseudococcidae) on coleus. - J. Entomol. Res. Soc. 13(2): 53-59.

Goodman D. 1982: Optimal life histories, optimal notation and the value of reproductive value. Am. Nat. 119: 803-823.

Gautam R.D. \& Parasram S. 1996: Dossier on Cryptolaemus montrouzieri (Mulsant) (Coccinellidae: Scymninae), a Potential Biological Control Agent for the Hibiscus Mealybug, Maconellicoccus hirsutus (Green) in Trinidad and Tobago, West Indies. Caribbean Agricultural Research and Development
Institute. Under TCP/RLA/6719 of the Food and Agriculture Organization of United Nations, $12 \mathrm{pp}$.

Hernandez H.G., Janson M.W. \& ReImer N.J. 1999: Impact of Pheidole megacephala (F.) (Hymenoptera: Formicidae) on the biological control of Dysmicoccus brevipes (Cockerell) (Homoptera: Pseudococcidae). Biol. Contr. 15: 145-152.

HuAnG Y.B. \& CHI H. 2013: Life tables of Bactrocera cucurbitae (Diptera: Tephritidae): with an invalidation of the jackknife technique. - J. Appl. Entomol. 137: 327-339.

IZHEVSKY S.S. \& ORLINSKY A.D. 1988: Life history of the imported Scymnus (Nephus) reunioni (Col.: Coccinellidae) predator of mealybugs. - Entomophaga 33: 101-114.

Jervis M.A. \& Copland M.J.W. 1996: The life cycle. In Jervis M.A. \& Kidd N.A.C. (eds): Insect Natural Enemies. Practical Approaches to their Study and Evaluation. Chapman \& Hall, London, pp. 63-161.

Joyce A.L., Hoddle M.S., Bellows T.S. \& Gonzalez D. 2001: Oviposition behavior of Coccidoxenoides peregrinus, a parasitoid of Planococcus ficus. - Entomol. Exp. Appl. 98: 49-57.

Kairo M.T.K., Pollard G.V., Pterkin D.D. \& Lopez V.F. 2000: Biological control of the hibiscus mealybug, Maconellicoccus hirsutus Green (Hemiptera: Pseudococcidae) in the Caribbean. - Integr. Pest Manag. Rev. 5: 241-254.

Kontodimas D.C., Milonas P.G., Stathas G.J., Economous L.P. \& KaVAlLiERAtos N.G. 2007: Life table parameters of the pseudococcid predators Nephus includens and Nephus bisignatus (Coleoptera: Coccinellidae). — Eur. J. Entomol. 104: 407-415.

LeSLIE P.H. 1945: On the use of matrices in certain population mathematics. - Biometrika 33: 183-212.

LEwIS E.G. 1942: On the generation and growth of a population. - Sankhya 6: 93-96.

Löbl I. \& Smetana A. (eds) 2007: Catalogue of Palearctic Coleoptera. Vol. 4: Elateroidea, Derodontoidea, Bostrichoidea, Lymexyloidea, Cleroidea and Cucujoidea. Apollo Books, Stenstrup, $935 \mathrm{pp}$.

Mani M. \& Thontadarya T.S. 1989: Field evaluation of Cryptolaemus montrouzieri Muls. in the suppression of Maconellicoccus hirsutus green on grapevine. - J. Biol. Contr. 2: 14-16.

MeYerdirk D.E., Khasimuddin S. \& Bashir M. 1988: Importation, colonization and establishment of Anagyrus indicus (Hym.: Encyrtidae) on Nipaecoccus viridis (Hom.: Pseudococcidae) in Jordan. - Entomophaga 33: 229-237.

Moghadam M. 2006: The mealybug of Southern Iran (Homoptera: Coccoidea: Pseudococcidae). - J. Entomol. Soc. Iran 26(1): 1-11

Mossadegh M.S., Eslamizadeh R. \& Esfandiari M. 2008a: Biological study of mealybug Nipaecoccus viridis (New.) and possibility of its biological control by Cryptolaemus montrouzieri Mul. in citrus orchards of North Khuzestan. In: Proceedings of the $18^{\text {th }}$ Iranian plant protection congress, Hamadan, Iran, 24-27 August 2008. p. 35.

Mossadegh M.S., Esfandiari M. \& Heidarynia Z. 2008b: The relationship effects of symbiotic ants on biological control of $\mathrm{Ni}$ paecoccus viridis (New.) by Cryptolaemus montrouzieri Mul. in citrus orchards of North Khuzestan. In: Proceedings of the $18^{\text {th }}$ Iranian Plant Protection Congress, Hamadan, Iran, 24-27 August, 2008. p. 36.

Mossadegh M.S., Vafaei S.H., Zarghami S., Kocheili F., Farsi F., Alizadeh M.S. \& ReZaei N. 2012: Natural enemies of Phenacoccus solenopsis Tinsely (Sternorrhyncha: Coccoidea: Pseudococcidae) in Khuzestan, Iran. In: Proceedings of the $20^{\text {th }}$ Iranian Plant Protection Congress, Shiraz, Iran, 24-27 September 2012. p. 216.

Muniappan R., Meyerdirk D.E., Sengebau F.M., Berringer D.D. \& REDDY G.V.P. 2006: Classical biological control of the papa- 
ya mealybug, Paracoccus marginatus (Hemiptera: Pseudococcidae) in the republic of Palau. - Fla. Entomol. 89: 212-217.

Mustu M. \& Klincer N. 2013: Life table and some feeding features of Nephus kreissli fed on Planococcus ficus. - Phytoparasitica 41: 203-211.

Nechols J.R. 1995: The spherical mealybug. In Nechols J.R., Andres L.A., Beardsley J.W., Goeden R.D. \& Jackson C.G. (eds): Biological Control in the Western United States. Accomplishments and Benefits of Regional Research Project W-84, 1964 1989. University of California Press, Division of Agricultural and Natural Resources, Oakland, CA, pp. 164-165.

Persad A. \& Khan A. 2002: Comparison of life table parameters for Maconellicoccus hirsutus, Anagyrus kamali, Cryptolaemus montrouzieri and Scymnus coccivora. - BioControl 47: $137-149$.

Ramindo A.A.C. \& van Harten W.A. 2000: An annotated checklist of the Coccinellidae (Insecta: Coleoptera) of Yemen. Fauna of Arabia 18: 211-243.

Sharaf N.S. \& Meyerdirk D.E. 1987: A review of the biology, ecology and control of Nipaecoccus viridis (Homoptera: Pseudococcidae). - Misc. Publ. Entomol. Soc. Am. 66: 1-18.
Solangi G.S., Lohar M.K., Abro G.H. \& Buriro A.S. 2012: Biology and release of exotic predator Cryptolaemus montrouzieri Mulsant on mealybug Phenacoccus solenopsis Tinsley at Tandojam. - Sarhad J. Agric. 28: 429-435.

Solangi G.S., Karamaouna F., Kontodimas D., Milonas P., Lohar M.K., Abro G.H. \& Mahmood R. 2013: Effect of high temperatures on survival and longevity of the predator Cryptolaemus montrouzieri Mulsant. - Phytoparasitica 41: 213-19.

Yigit A. \& CANHILAL R. 1998: Introduction into East Mediterranean region of cold tolerant ecotypes of the citrus mealy bugs Predator Cryptolaemus montrouzieri their adaption to the region. - Bitki Koruma Bül. 38(1-2): 23-41.

Yu J.Z., Chл H. \& Chen B.H. 2005: Life table and predation of Lemnia biplagiata (Coleoptera: Coccinellidae) fed on Aphis gossypii (Homoptera: Aphididae) with a proof on relationship among gross reproduction rate, net reproduction rate and preadult survivorship. - Ann. Entomol. Soc. Am. 98: 475-482.

Yu J.Z., Chi H. \& Chen B.H. 2013: Comparison of the life tables and predation rates of Harmonia dimidiata (F.) (Coleoptera: Coccinellidae) fed on Aphis gossypii Glover (Hemiptera: Aphididae) at different temperatures. - Biol. Contr. 64: 1-9.

Received July 3, 2013; revised and accepted November 11, 2013 Prepublished online February 15, 2014 